\title{
LITIGATION, THE ANGLO-SCOTTISH UNION AND THE HOUSE OF LORDS AS HIGH COURT, 1660-1875*
}

Accepted for publication in the Cambridge Historical Journal https://www.cambridge.org/core/journals/historical-journal

\author{
PHILIP LOFT \\ Wolfson College, University of Cambridge
}

\begin{abstract}
This article examines the role of House of Lords as high court from the Restoration of 1660 to the passage of the Appellate Jurisdiction Act in 1876. Throughout this period, lay peers and bishops judged appeals on civil law from the central courts of England and Wales, Ireland (aside from between 1783 and 1800) and Scotland after the Union of 1707. It has long been known that the revolution of 1688-89 transformed the ability of parliament to pass legislation, but the increased length and predictability of parliamentary sessions was of equal significance to the judicial functions performed by peers. Unlike the English-dominated profile of eighteenth-century legislation, Scots constituted the largest proportion of appellants between 1740 and 1875. The lack of interaction between Westminster and Scotland is often seen as essential to ensuring the longevity of Union, but through comparing the subject matter of appeals and mapping the distribution of cases within Scotland, this article demonstrates the extent of Scottish engagement. Echoing the tendency of Scottish interests to pursue local, private and specific legislation in order to insulate Scottish institutions from English intervention, Scottish litigants primarily sought to maintain and challenge local privileges, legal particularisms and the power of dominant landowners.
\end{abstract}

Historians have long recognised the dramatic rise in parliamentary legislation passed at Westminster after the revolution of 1688-89. The annual meeting of parliament enabled propertied interests to lobby for more than 13,600 acts in the 112 years to 1800 , being five times higher than the 2,700 acts passed in the 203 years from 1485 to $1688 .{ }^{1}$ This article explores an additional development in parliamentary power that was of particular significance to the functioning of Britain as a multinational state. In contrast to many lower courts that saw a collapse in their caseload during the eighteenth century, the revolution of 1688-89, and then the Union of 1707, caused the Lords to experience a great increase in its appeals business. Building on the work of Nicholas Phillipson and John Finlay who have demonstrated the disproportionately large number of Scottish legal cases at Westminster 
LITIGATION AND THE UNION OF 1707

after 1707 , this article systematically sets out the trajectory of some 8500 appeals presented to the Lords from 1660 to $1875 .^{2}$ It presents reasons for the large number of Scottish cases, surveys the subjects of appeals via way of sampling and demonstrates the often limited and particular ends to which they were pursued, and maps the geography of cases from Scotland to 1800.

The relationship between Scotland and Westminster after the Union was portrayed in some older accounts as a limited and often hostile one, primarily reflecting the desire of Scottish interests to maintain a separate zone of autonomy from the English-dominated British state. Protected by articles in the Union treaties and acts of the Scottish parliament passed shortly before 1707 defending the status of the Presbyterian church, Scottish criminal and private law, and the convention of royal burghs (an assembly of burgh commissioners employed to levy taxes and resolve burgh disputes), Scottish interests withdrew into their own governing institutions for much of the eighteenth century. As has been argued, after 1707 Scotland had a 'coherent and integrated set of structures, which were often able to shrug off or isolate themselves from London influence' ${ }^{3}$ Scottish interests looked to Edinburgh law courts, the convention and individual burghs to resolve conflicts and advance schemes for economic improvement, not Westminster. It was the only reasonable response to being 'in bed with an elephant', with England dominant economically, demographically, and politically (through constituting the majority of members in parliament). ${ }^{4}$ Change that did come from London was often in the form of coercive imposition or direct state subsidies from the central state, with little scope for local initiative by Scottish interests. ${ }^{5}$

Recent histories have amended this narrative of withdrawal and disengagement, and rather demonstrated that after 1707 Scottish interests were primarily pursuing only a 
selective autonomy aimed at avoiding the erosion of the established institutional order in Scotland. There was certainly little legislative integration with the British state until after the final Jacobite rising of 1745, and neither the Court of Session or convention of royal burghs experienced substantial legislative reform until the nineteenth century. ${ }^{6}$ The Union initially resulted in a marked fall-off in legislation relating to Scotland. General legislation regulating religion, poor relief, elections and taxation shrank some eighty-five per cent between 1707 and 1727 compared to the activity of the Edinburgh parliament between 1689 and the Union. Local legislation relating to individual burghs and counties was less affected but still fell by thirty per cent. ${ }^{7}$ Scottish interests also avoided petitioning on proposed legislation, presenting only 230 collective petitions between 1707 and 1755 compared to 5500 from England and Wales. ${ }^{8}$

However, following the Jacobite rising of 1745 Westminster passed an increasing amount of legislation relating to Scotland, and after 1760 Scottish interests and highland landowners gradually became more active as lobbyists in seeking legislation to promote the fisheries and linen industry. ${ }^{9}$ Echoing their often defensive and limited legislation that sought to empower and legitimize local developments within Scotland, were a growing number of legal appeals from the Session and Scottish Exchequer to Westminster. The legislative influence of the eighteenth-century Westminster parliament was only infrequently felt on Scottish social policy, urban improvement schemes, or the rural economy, as research by Bob Harris and Julian Hoppit has shown. ${ }^{10}$ But this article demonstrates that the judge-made law of the House of Lords ensured that parliamentary influence was brought to bear on these issues. These appeals show that Scottish law was far from a point of divergence between the two nations, and instead complimented the profile of Scottish legislative engagement, awarding it greater geographic range and drawing in 
LITIGATION AND THE UNION OF 1707

further subjects of dispute to arbitration at Westminster. ${ }^{11}$ Section one demonstrates that Scottish appeals were large in number and that many dealt with issues underrepresented in legislation such as burgh powers and religion; section two establishes the number of decisions of Scottish courts that were altered at Westminster; section three shows that appeals dealt with highland, island and rural disputes in addition to those of Scotland's cities.

The data for this article is produced from the Lords journals. These minutes of proceedings list each case, the individuals involved, the dates of hearing and the decision of peers. This information has been supplemented by the petitions of the appellants and plaintiffs that provide us with the social rank and residence of litigants, and the subject details of the case..$^{12}$ During this period, only civil causes could be appealed to the Lords. ${ }^{13}$ Lay peers and bishops would pass judgment, but after the 1840 s a convention developed that decisions would be deferred to supporting judges. It was not until the Appellate Jurisdiction Act of 1876 that law lords were introduced. ${ }^{14}$ Significantly, although contemporaries were willing to describe the Lords as the 'high court of judicature' and 'supreme', peers only very rarely invalidated statutes, as to have done so would have been an open challenge to parliamentary supremacy. ${ }^{15}$ Despite these caveats, it was the highest civil court for the British Isles and was a permanent feature in the legal system after 1688.

The result of counting appeals presented to the Lords from 1660 to 1875 are displayed in graph one. In graph two, the number of cases from each nation are shown. In order to show the general trend more clearly, in both charts the session totals of appeals are presented as a moving average. Echoing the pattern found by Julian Hoppit for the growth of 
parliamentary legislation, the overall number of appeals were low from 1660 to 1688 , then increased greatly to peak in the 1720s, recovered from their mid-century low after 1760 and experienced a further and sustained rise after $1800 .{ }^{16}$ This growth in cases reflected the increased frequency of parliamentary sessions after 1688-89. Fourteen appeals were presented on average each session during the Restoration, but from 1760 to 1800 this rose to twenty-two, and reached forty-two from 1800 to 1840 . As sessions varied in length, the ratio of appeals presented to the number of days that peers sat is also plotted in graph one. From $1660-88$ the ratio is 0.2 and for $1760-1800$ 0.4. Business peaked between 1800 and 1840 at 0.6 , and fell back to 0.5 in $1840-75$.

Graph 1: Number of appeals, 1660-1875 per session and sitting day (seven session moving average)

Graph 2: Number of appeals from each nation, 1660-1875 (seven session moving average)

As graph two shows, the expanding jurisdiction of the Lords was crucial to sustaining its caseload from the 1730s until the recovery of English appeals in the last quarter of the eighteenth century. Scottish appeals rapidly rose in both number and proportion after 1707, whilst English appeals experienced a cyclical decline and were usually smaller in number than Scottish appeals from 1740 to the 1860s. Rising legal costs in the English court of Exchequer had seen its number of new cases declining to forty per cent of 1685 levels in 1735 , and this pattern was echoed in Chancery, with the total number of new cases introduced each year contracting from 5,660 in 1685 to only 1,544 in $1785 .{ }^{17}$ This decline fed through into the number and profile of English cases received on appeal in the Lords. The slight fall in the number of appeals after 1840 compared to the previous forty years was the result of the decline in Scottish cases, which fell from an average of 42 each session to 25 from $1800-35$ to $1857-75$. In total, from 1707 to 1800 there were some 1,400 Scottish 
LITIGATION AND THE UNION OF 1707

appeals, 1,200 from England and Wales, and 500 from Irish courts. Scottish dominance continued between 1801 and 1875, with an additional 2,600 Scottish appeals to 1,400 from England and Wales, and a further 500 from Ireland. The repeal of the Declaratory Act in 1783 reasserted the supremacy of the Dublin parliament in judicial matters over that at Westminster, and resulted in a collapse of Irish appeals until the Anglo-Irish Union of $1801 .^{18}$ Few appeals came from North American courts during this period, a fact that enabled Benjamin Franklin to demonstrate American independence from the British parliament. ${ }^{19}$

The rise in the number of appeals after 1689 reflected the presence of more frequent, longer and predictable parliamentary sessions. Whilst the high demand to appeal was essential to increasing the caseload of peers, without procedural and organisational reform few cases would reach judgement. Irregular parliamentary sessions during the Restoration had limited the ability of peers to streamline the appeals process and limit the amount of vexatious litigation. The creation of a predictable parliamentary calendar and the increasingly stable length of Westminster parliamentary sessions after 1689 enabled peers to disallow appeals brought more than two years after the judgement of the lower court, and refuse unprosecuted appeals from being reintroduced in another parliamentary session. Peers also placed new barriers on appealing in the aim of reducing the number of vexatious appellants, allowing more time for genuine appeals. New standing orders of 1702 increased the costs of appealing by requiring the printing of case papers and for counsel to certify that the appeal was reasonable. ${ }^{20}$ The lack of similar reforms in Scotland had meant that its parliament gave judgement on only nine of the fifty-three cases presented to it between 1689 and $1707 .{ }^{21}$

The presence of a disproportionate number of Scottish appeals in the 'foreign' jurisdiction of Westminster required that in addition to litigant demand, there existed the right and ability to appeal from the Session, and the reassurance that an English-dominated 
court would respect Scottish and local forms of law and not use appeals to enable a general English intervention into Scottish governing institutions. In the first instance, the procedures of the Session were responsible for enabling the high number of Scottish appeals between 1707 and its reform in the nineteenth century. Its judgements were often insufficiently explained, decided on the smallest majority of one judge, and were justified by different judges applying competing reasons. ${ }^{22}$ The relative ease in appealing Session decisions enabled its far higher caseload compared to English central courts (shown in graph three) to be felt at Westminster. The combined caseload of the English courts of Chancery, Exchequer, King's Bench and Common Pleas in 1750 was equal to one case in these courts to every 827 people. This compared to one case in the Session for 608 Scots in 1755 (the year of Alexander Webster's Scottish census), and rates increased to 524 Scots per case in 1790, which was the peak of its business in this period..$^{23}$

\section{Graph 3: Cases presented to British law courts, 1745-1875.}

The gradual nineteenth-century decline in Scottish appeals resulted from the reform of Session procedures. Seven statutes passed between 1808 and 1830 helped reduce the number of appeals by introducing a review hearing of cases before leave to appeal from the Session was granted. ${ }^{24}$ The costs of appealing to Westminster were also increased in an attempt to discourage speculative or delaying appeals through a new standing order of 1811 , which required parties to deliver their printed cases within a month of their appeal being made. ${ }^{25}$ These reforms restricted the ability and increased the costs of appealing to the Lords from the court, but the rising inefficiency that the Session dealt with its own caseload also meant that fewer cases reached judgement. Aside from its caseload falling forty-four per cent between 1795 and 1831, the rate of judgement by Session judges halved 
LITIGATION AND THE UNION OF 1707

between 1819 and $1839 .{ }^{26}$ This declining caseload would have been starker if it had not been offset by the removal of cases from the Commissary, Exchequer and Admiralty courts to the Session. ${ }^{27}$

The nature of Session judgements and its high caseload provided a potential pool of Scottish appellants, and partially explains the higher number of Scottish cases compared to those from other nations. But it was additionally necessary for Westminster to prove itself capable of judging law from a jurisdiction that was 'foreign' to the majority of its members and to act in a circumspect fashion when intervening in Scottish law and society. The sixteen Scottish representative peers were greatly outnumbered by English peers that numbered 173 in 1700 and 267 in 1800, and during the eighteenth century even senior Scottish lawyers such as the Lord Advocate would often act as the junior to an English counsel. ${ }^{28}$ Care was also required when navigating the Union treaty, for it declared Scottish private law unalterable unless for the 'evident utility of the subjects within Scotland', and the rights and privileges of the royal burghs were to 'remain entire after the Union'. A Scottish act of 1706 placed further limitations upon parliament and the twenty-six bishops who sat in the Lords by stating that the place and status of the Presbyterian Kirk would remain for 'all time coming' ${ }^{29}$

Although the issue of judging Scottish cases at Westminster seemed problematic in the context of the need to preserve Scottish legal distinctiveness, the subjects of appeals and the nature of the disputed law allayed many of these problems. The subjects of these appeals are shown in table one. ${ }^{30}$ This data has been produced by examining twenty-six parliamentary sessions from 1660 to 1875 . The one session in each decade that received the closest number of appeals to the average of that decade was investigated, producing a sample of 954 cases, or eleven per cent of the total number presented to the Lords. ${ }^{31}$ This includes around four 
hundred cases for Scotland and England and Wales, respectively, with the remainder from Ireland. Cases may be categorized several ways. In table one, 'business disputes' is restricted to physical goods, whilst cases over stocks and credit have been listed under 'debts and bonds'. The category 'miscellaneous' contains a plethora of topics, ranging from policing to the regulation of theatres and the costs of litigation. 'Markets and tax' includes cases over public and local finance, trading privileges, and national economic regulations.

Table 1: Subjects of appeals by nation in sample sessions, 1660-1875 (as percentage and number of prosecuted appeals)

This sample shows that at least 87 per cent of prosecuted cases from Ireland and 79 per cent in England and Wales dealt with disputes over debt, inheritance and land titles in each of the four periods, but only between 64 and 78 per cent of Scottish prosecuted cases did so. This means that in the majority of appeals heard by peers, conflicts centred on the ownership of land, debtor-creditor relationships and contested wills and inheritances. Although significant for social relations and for maintaining economic and social inequalities, these appeals were primarily personal in nature and did not threaten to draw issues of public policy into conflict at Westminster and upset Scottish legal cultures or governing institutions. One significant case in this regard was Gray v. Hamilton (1709). Peers reversed the judgement of the Session that Scots law should judge a dispute over a contract created in England because the appeal had been entered in a Scottish court. ${ }^{32}$ This decision confirmed that similar cases should continue to be governed by the jurisdiction in which the contract or bond had been entered into, removing one potential source of cross-fertilisation or assimilation between the legal systems of the British Isles.

The subjects raised in the sampled cases do suggest that Scottish litigants brought more appeals concerned with issues of public policy than English, Welsh or Irish appellants. 
LITIGATION AND THE UNION OF 1707

But the nature of these cases continues to endorse the view that Scottish interests were primarily engaged with Westminster on particular and specific privileges and points of law, rather than seeking general reform. Cases dealing with the powers of royal burghs over taxation, market regulation, poor relief and urban improvement schemes centred on disputes over localised and specific privileges. English boroughs were far from immune to legal conflict on these issues, but the sample suggests that they were less frequently involved in appeals to the Lords. ${ }^{33}$ One reason why Scottish interests came in larger numbers and did not find it necessary to lobby for local legislation on the scale of English boroughs was that pre-1707 Scottish acts could be interpreted as having fallen into desuetude. ${ }^{34}$ This was a process by which the development of a new practice could be argued to have overturned the meaning of the pre-existing statute. It was a significant mechanism, for it meant that English peers were not being asked to judge matters of Scottish law, but matters of fact. Resolution of these cases centred on establishing whether a particular custom had developed and the history of the enforcement of the statute. Secondly, this made legal innovation the result of local developments within Scotland.

This culture of specific improvements pursued by the desuetude process and the attempted protection for local particularisms and privileges characterised many burgh appeals. ${ }^{35}$ A case challenging the power of Edinburgh magistrates to restrict the trade and price of tallow in 1714 following a two-decade long dispute between the fleshers, butchers and candle makers of the city saw peers judge that the powers were now in desuetude and the revival of constraints by local byelaws was insufficient. ${ }^{36}$ Underlining the limited nature of the judgement, Glasgow magistrates issued new regulations maintaining the privileges of candle makers as early as $1718 .{ }^{37}$ A similar attempt to revive a local exemption from salt duties for newly-exploited salt pans by the earl of Mansfield in Dumfriesshire in 1814 was also 
found by peers to have fallen into desuetude due to the privilege failing to be reasserted since the ending of Scottish salt duties in $1671 .{ }^{38}$ Arguments that statutes from the fifteenth and sixteenth centuries limiting the use of fixed netting traps had fallen into disuse and could not be revived were invoked in favour of an appeal to introduce new fishing machinery on the Tay in $1816 .{ }^{39}$ In the case, the appellants were seeking a geographically restricted judgement that would exempt their area of the Tay from the general acts governing the Scottish fisheries. They did this through claiming that their saltwater sections were in the firth, not the river. Pleading exemptions such as these was far easier than lobbying for wider reform because it avoided the clashing of interests that proposing a new national law would create- in this case with the duke of Atholl and the burgh of Perth, in whom the leasing of rights on the Tay were vested, and St Andrews, Montrose, Dumfries and Dundee whose opposition had led to the defeat of four proposed acts between 1823 and $1827 .{ }^{40}$ Disputes over local customary practices within particular geographical boundaries also required peers to merely judge the presence of the custom. This they did in the 'rabbit case' of 1813, which followed a riot by golfers and inhabitants of St Andrews in defence of their claimed customary privilege to kill rabbits damaging the links. This custom had come into conflict with the right of the lessees to use their property as they wished, in this case by maintaining rabbit warrens. ${ }^{41}$

Burghs primarily used appeals as a means to maintain and strengthen their local jurisdictions and defend their privileges from the encroachment of competing county bodies or landed elites. They therefore echoed the motivation for local legislation in England, as characterised by Paul Langford, in that they sought advantage over their local rivals rather than a greater national advance. ${ }^{42}$ The deep-rooted interest of the burgh of Perth in the Tay fisheries illustrates this. In 1757, magistrates sought to maintain their privileges against Lord Gray by arguing that his fisheries were interfering with those belonged to the town. ${ }^{43}$ Their 
LITIGATION AND THE UNION OF 1707

concern for their fishing privileges were echoed a century later in an appeal of 1862 in which the burgh argued that another new machine in the Tay was impacting on their fishing grounds, but the so-called 'Bermondsey boat' was declared legal by the Lords. ${ }^{44}$ The boat had been active since 1843, but increasing competition from the new Perth-Dundee railway after 1837 had undermined the burgh's finances and encouraged a redoubling of efforts to extract profits from their fisheries. Such concerns for maintaining or extending the jurisdictional boundaries and privileges of towns were also responsible for the growing litigation against railway companies in the nineteenth century. The burgh of Linlithgow in 1849 sued the Edinburgh and Glasgow Railway company for payment of tolls on all commodities passing through the burgh, in an attempt to revive ancient toll duties. Edinburgh fleshers had already claimed an exemption in the 1620 s, but the article of Union protecting the privileges of the royal burghs was invoked in favour of the power. Despite winning their case twice in the Session, peers saw the burgh as having failed to maintain the levy on the travel of coaches through the town. The lack of a mechanism in the railway act to allow a toll keeper to come upon the railway and stop the train to collect the toll meant that any attempt to impose local duties would be seen as trespassing. ${ }^{45}$

A similar process of local and partisan litigation were responsible for amending the constitutions of burghs and the shape of the electorate. A general revision of the laws governing the Scottish electorate waited until the 1832 Reform Act, and this left a number of weaknesses in the law that enabled more than six hundred cases to come to the Session between 1796 and $1816 .{ }^{46}$ The creation of 'parchment barons' (as opposed to real freeholders) caused much local partisan tension, in that their titles were empty paper grants made to enlist them as subservient voters by candidates. ${ }^{47}$ This practice was the result of several deficiencies in pre-Union law over what constituted a meeting of freeholders, debates 
over the valuation of land as a qualification to vote, and the fact it was the freeholders themselves determining who was eligible to be on the roll at these meetings. ${ }^{48}$ The bringing of cases disputing the qualifications of individual voters multiplied the number of suits, increased the costs of litigation, and strengthened local hostilities. These appeals were expressly partisan ones, and often reflected the attempts of burghs or individuals to maintain their independence against the intervention of competing landowner influence. Some thirteen cases came to the Lords in 1768 regarding the entering of new freeholders on the electoral roll for Angus. ${ }^{49}$ This reflected the growing competition between the Strathmore and Panmure interests for the parliamentary seat, and the newly-found patronage that came from the purchase of land by William Maule, the earl of Panmure and MP, and its distribution to create loyalist voters. The earl had been unopposed in the two previous elections, but the enfranchisement of new electors successfully carried the contest for him, with all but one case judged in his favour by peers. The collapse of a coalition in Renfrewshire in the 1810s established in order to challenge the McDowall interest that had held the seat since the $1790 \mathrm{~s}$ also led to legal challenges over the enfranchisement of new life-renters that had resulted from their recent purchase of an estate. ${ }^{50}$ Similar dynamics produced appeals in Aberdeenshire following the creation of twenty-six fictional voters and the collapse of an electoral truce between the duke of Gordon and the earl of Fife in $1790 .{ }^{51}$ The decline of these disputes after 1832 certainly contributed to some of the fall in Scottish appeals, as table one suggests.

This uncoordinated and limited application of Westminster parliamentary power largely avoided causing nation-wide controversies that the general revision of the constitutions and privileges of all Scottish burghs would have. One case before 1800 was fiercely contested by the convention precisely because it did threaten their collective 
LITIGATION AND THE UNION OF 1707

privileges. The dispute centred on the monopoly power of royal burghs to conduct overseas trade. No legislation reforming this was passed until 1846, and the rights had been confirmed in Scottish acts of 1672, 1690 and 1693 and by the twenty-first article of Union protecting the rights of the royal burghs as they existed in $1707 . .^{52}$ 'Unfree' towns had previously sought to undermine this exclusive privilege, and Glasgow had gone to law against the unfree merchants of Greenock and Linlithgow versus traders in Bo'ness during the $1670 \mathrm{~s} .{ }^{53}$ In the eighteenth century, the increasing prosperity of Stromness compared to the royal burgh of Kirkwall in Orkney due to its links to the Hudson Bay Company produced demands for it to trade without reference to Kirkwall. This dispute entered the Session in 1743, and continued until the Lords in 1758 affirmed the right of Stromness and other unfree towns to trade independently from their neighbouring royal burghs. ${ }^{54}$ The convention of royal burghs was responsible for sustaining the appeal, helping Kirkwall to fund the litigation in defence of its trade. The money it expended was the second greatest amount it had spent lobbying Westminster since the fisheries act of 1727 , and surpassed only by its efforts to procure a linen act in the same year as the appeal. ${ }^{55}$ This trade monopoly had been initially granted as a concession to the royal burghs in exchange for their payment of the Scottish land $\operatorname{tax}^{56}$ The increased tensions in Orkney were also the result of Kirkwall attempting to force neighbouring unfree traders to contribute to its quota of taxation. This was done without legislative reform, and occurred in line with the reference in the Union treaty that the levy would be collected as it was previously. However, the Lords refused to sanction the demand of burghs to seize the property of unfree merchants, and thus ensured that Scottish land tax administration suffered a degree of legal confusion and stagnation. ${ }^{57}$ In addition to the economic significance of the case, the right to trade was also a matter of status for Stromness. The town 
commemorated the victory on its coat of arms when granted burgh status in 1817 , and named a street in honour of the merchant Alexander Graham who had led the cause. ${ }^{58}$

Given the generally cautious nature of appeals dealing with private law and the privileges of burghs, it is perhaps surprising that it was the status of the Presbyterian Kirk in which the judgements of the Lords had their most disruptive impact on Scottish society. The growing use of the English prayer book by Scottish Episcopalians following the revolution of 1688-89 had led to a backlash by the Presbyterian church which had sought to suppress such meetings, fearing that they incubated Jacobitism and presented a threat to the status of Presbyterianism that only been recently re-established by the Scottish convention of $1689 .{ }^{59}$ These prosecutions culminated in the action taken against James Greenshields in 1709, who had been practising the English liturgy in Edinburgh to serve an English congregation. His appeal received judgement in the Lords in 1710 , who determined that no law of conformity existed in Scotland and that it was legal for a minster of the English church to practice in Scotland. For Presbyterians, this was an attack on the established national church and the Union itself, with the decision denounced in addresses from Edinburgh and Haddington. ${ }^{60}$

For Episcopalians, the case provided a window in which they could pursue legislation that would better accommodate them with the British state. Their lobbying led to the passage of the Scottish Toleration Act and the reintroduction of lay landowner patronage over the appointment of ministers in 1711, the latter producing an enduring grievance of the Presbyterian Kirk. This led to annual protests by the General Assembly to the monarch, but when evangelical groups became the dominant group in the assembly during the 1830 s they assumed a more confrontational approach towards the state. In 1834 , the assembly passed the Veto Act that reinstated the right of parishioners lost in 1711 to reject a minister nominated by their patron. ${ }^{61}$ In doing so, it was expected that civil courts would respect the 
LITIGATION AND THE UNION OF 1707

right of the Kirk to regulate the appointment of its own ministers, but this was not the case. Increased tensions between lay landowners and the Kirk came to a head when Robert Young, the nominee of the earl of Kinnoul for the parish of Auchterarder in Perthshire, had gained the support of only three of his three thousand parishioners. Three cases on the issue were taken to the Session and the Lords, who both determined that the Veto Act had infringed the rights of patrons as established by statute (though the Session was divided, eight to five). ${ }^{62}$ The judgement went further than this, in ruling that the Kirk was not an unalterable part of the constitution and was rather subject to the power of a sovereign parliament. This escalation of the patronage controversy into a clash of jurisdictions and a clear statement that the Kirk held no supreme spiritual independence, provoked the secession of around a third of Presbyterian clergy in order to found the Free Church of Scotland in $1843 .{ }^{63}$ The legacy of the 1710 Greenshields case and the schism in the national church more than a century later was something that few other appeals could compare to, either in their consequences for Scottish society or for its governing institutions that were otherwise successfully entrenched between the Union of 1707 and the legislative reforms of the nineteenth century.

II

When seeking to establish the significance of this interaction between Scottish litigants and Westminster to the functioning of Union, we also need to take account of the extent that the Lords altered or varied the decisions of Scottish courts. In this period, central state justice did not displace private forms of law designed to manage relations between individuals and neighbouring interests, with the right to appeal increasingly employed as a means to force compromise between the litigating parties. The striking aspect of the rise of appeals towards the end of the eighteenth century is that it coincided with increasing numbers of appellants formally withdrawing their cases before any hearings occurred 
(shown in graph four), and doing so with the permission of peers. Regularly, between twenty and twenty-five per cent of Scottish cases were withdrawn, but this reached forty per cent in $1780-90$ and $1830-40$. This was not due to rising rates of inefficiency within the Lords, which dealt with its increased caseload effectively. Graph five, based on data from a contemporary report, suggests that there existed a stable relationship between the number of appeals and time spent hearing them.

\section{Graph 4: Decisions on Scottish appeals, 1707-1840}

Graph 5: Relationship between the number of appeals and days spent hearing, 1756-1792 (seven session moving average)

Instead, appeals increasingly functioned as a threat to force negotiation or speed up an informal settlement. In doing so, appellants guaranteed that their engagement with Westminster could only affect the locality and particular individuals involved in the case. Between 1756 and 1793, nearly eighty per cent of formally withdrawn Scottish cases were done so with the consent of both parties, suggesting that appeals were employed as a means of arbitration. ${ }^{64}$ The 'mere dread of delays' led to compromise. One appeal forced the defendant to 'deliberately abandon one half of his claim' ${ }^{65}$ Others used the threat 'in order to embarrass and wear out the petitioners, and to force them into a compromise'. ${ }^{66}$ Edinburgh magistrates had decided not to challenge the returns of the election of 1817 any further than the Session, the suit having already lasted three years and cost four thousand pounds, and Montrose magistrates were 'for the sake of peace...willing to acquiesce' on a tithe case. ${ }^{67}$ This meant that in some periods, for up to forty per cent of Scottish litigants, the significance of the right to appeal lay in the ability to extract particular and personal concessions from the opposing party rather than seeking a wider reform of the law. 
LITIGATION AND THE UNION OF 1707

Despite the growth of appeals, the greater involvement of Scottish lawyers in lawsuits as they gained experience practising in the Lords, and the changing subject matter, graph six shows that the rates in reversal of the cases that went to judgement remained remarkably consistent throughout this long period: between thirty and forty per cent. ${ }^{68}$ The exception to this is the initial period before 1720 when over fifty per cent of appeals from the Session were reversed, but this was due to the jurisdiction of the Session over twenty-five cases dealing with the forfeiting of Jacobite estates being declared as null and void. 69

\section{Graph 6: Decisions on Scottish appeals that went to judgement, 1707-1875}

This high number of reversals did not reflect any systematic mistreatment of appeals by non-Scottish peers. The proportion of Scottish appeals overturned was similar to that in other European courts whose jurisdiction contained multiple legal systems. In France, the Parisian Parlement also reversed around a third of cases that came before it, and the Castilian appellate court reversed the same proportion. ${ }^{70}$ These judgements delivered by peers were also overwhelmingly consensual in nature. In the eight hundred divisions in the Lords from 1714 to 1784 , there were only fifty-one divisions on the eight hundred legal cases presented before 1733 , and five in the remaining fifty-year period on some fifteen hundred cases. ${ }^{71}$ Party and interest allegiances could influence the position that peers took on a case, but this did not occur on a regular basis. With regard to the Greenshields case, divisions did not occur on Anglo-Scottish lines because a number of Scottish peers were 'violently for him', whilst some fellow representative peers 'walked out of the appeal...knowing there was nothing to be said'. ${ }^{72}$ In the main, Scottish appeals remained limited and particular enough to avoid creating repeated tensions at the level of the British 
state. Instead, the motivating and resulting hostilities were contained within the locality from which the appeal came.

The particular nature of Scottish appeals limited their use as a mechanism to reform Scottish society at the level of the nation state. Instead, the improvement of political economy and governance remained highly varied across the Scottish nation. Section three considers the geography of eighteenth-century Scottish appeals. The reach of British power was mixed in post-Union Scotland, and particular local dynamics and tensions remained the primary context in which appeals were motivated and contained.

At a general level, the emergence of a unified British state is frequently argued to have supported its early industrialisation and mobilisation of military power. ${ }^{73}$ Britain after 1707 had a single parliament, and although it continued to contain different national legal systems and institutions, these were centralised in Westminster Hall for England and Wales, and in the Session and Exchequer for Scotland. But the composite nature of the state endured. Legal systems and parliaments were not universally drawn upon, with substantial geographic variation in their employment and effectiveness. Christopher Brooks and Henry Horwitz both showed that London litigants formed the majority of plaintiffs in the courts of Chancery and Exchequer, and that the eighteenth-century decline in litigation reflected a decline in cases from the English localities. ${ }^{74}$ Although the business of the Session has not been mapped systematically, recent explorations suggest a similar absence of cases in highland and rural areas. ${ }^{75}$ Hoppit has demonstrated that just nineteen English counties 
LITIGATION AND THE UNION OF 1707

were collectively responsible for nearly seventy percent of economic legislation passed at Westminster before 1800. General legislation did also not often apply outside England, with only 457 of the 1,552 public statutes passed between 1707 and 1754 believed to be 'in force and use relative to Scotland' in the period. ${ }^{76}$

The reach of both parliamentary and legal power was therefore highly uneven. As graph two showed, there was clearly a much greater resort to the Lords as the high court by Scottish interests. But as map one demonstrates, the pattern of appeals also varied within Scotland. Because counties varied in their physical size and population, appeals have been mapped per thousand inhabitants. This is as a proxy for their economic size which was a factor influencing appeals on economic, land and credit issues. The map shows separately the four largest Scottish cities in 1800- Edinburgh (including Leith), Glasgow, Aberdeen and Dundee. The population figures are necessarily based on a snapshot, with Webster's census of 1755 providing the data. In contrast to the implementation of coercive penal polices or the collection of taxation, the British parliament experienced no difficulties in receiving appeals from relatively distant and inaccessible regions with low population densities and poor communication links. Appellants came from the geographic periphery, and only Bute sent no appeals before 1800. Islands sending appeals included Skye, Mull, North and South Uist, and those constituting the Northern Isles.

Map 1. Distribution of Scottish appeals, per thousand inhabitants, 1707-1800

Despite the fact that appellants had chosen to bring the state in on their own terms, their engagement still demonstrates a desire and ability of interests to call upon the British state to umpire disputes in local societies. However, the geography of appeals endorses Hoppit's findings that many Scottish counties were disengaged from Westminster during the 
eighteenth century. The two counties most active in seeking statutes sent the largest number of appeals, with Lanarkshire lobbying for 34 economic bills and 113 appeals, whilst Midlothian pursued 19 bills and 236 appeals from 1707 to 1800 . Counties such as Berwickshire or Peebles uninvolved in seeking economic legislation were also unengaged with the Lords as high court (sending 9 bills and 21 appeals, and 4 bills and 6 appeals, respectively). ${ }^{77}$ The traditional economic, population and political centres of Scotland dominated. The largest number of appeals were from the four largest population centres: Edinburgh sent 200 appeals (a seventh of the pre-1800 total), Glasgow 64, Aberdeen some 59 , whilst Dundee and the surrounding county of Angus sent 65 . Some 16 cases relating to overseas trade, not currently included on the map, were likely to be linked to these cities.

Cromarty stands out from this pattern, with a higher per capita appeal rate than Glasgow, because of its small population of 5,100 in 1755. But this did not mean that Cromarty was drawing itself closer to the British state than other areas of the highlands. The county experienced a short and fierce period of litigation in the 1760 s 'owing to the madness of elections' and attempts to enfranchise new voters. ${ }^{78}$ The seat had only eighteen electors, and had evenly split between William Pulteney (who was MP from 1768) and Sir John Gordon (MP from 1754). This concentrated period of litigation bankrupted the Gordons and enabled the Pulteney interest to be returned without opposition in $1780 .{ }^{79}$ No less than forty petitions were sent to the Session between 1765 and 1767 disputing the creation of new voters, and on a single day in 1770 Gordon lost three appeals in the Lords. ${ }^{80}$ Further appeals over the qualifications of the electorate in parliamentary and burgh elections during the 1750 s and 1790s (as the Pulteney regime unravelled when he moved seat to Shrewsbury) ensured that in the eighteenth century Cromarty interests primarily used Westminster as a place to umpire partisanship within the county. ${ }^{81}$ Reflecting the 
LITIGATION AND THE UNION OF 1707

subject profile of cases, disputes over inheritances, land titles and debt constituted its remaining appeals. In echoing the high rate of withdrawal of Scottish appeals, peers were unable to deliver judgement on cases dealing with the salmon fisheries and the 1790 election before they were withdrawn. ${ }^{82}$ Although a larger number of counties were engaged with Westminster via appeals rather than in the pursuit of legislation, the nature of these cases confirms the view that Scottish engagement with Westminster, especially in the eighteenth century, was intentionally localised, partial and limited. Their presence rarely reflected, or enabled, a systematic reworking and improvement of Scottish law at the national level.

IV

Legal histories of eighteenth-century Europe have typically stressed the decline in the caseloads of most civil courts compared to the height achieved in the seventeenth century. However, this article has demonstrated the continuing buoyancy of the Lords as a result of the increased regularity and length of parliamentary sessions after 1689 and its expanding jurisdiction that enabled appeals from Scottish courts to compensate for the fall in English and Welsh cases coming from Westminster Hall. The presence of these appellants reflected the effective management of a high caseload by the Session in Edinburgh and the efficiency that peers dealt with their legal business in Westminster.

Scottish law and its legal institutions, as protected in the Union treaties, has often been seen as an important conduit for a separate Scottish national identity, and a mechanism by which Scottish society could insulate itself from the dominance of England within the post-Union state. In other areas of state policy, notably the raising of taxes, the implementation of the poor law, and the enforcement of the penal statutes of the Bloody Code, it has been shown that the central state frequently found it difficult to impose its laws 
and policies on the periphery. ${ }^{83}$ In this, the British state was similar to many other European states in the early modern period in being multi-layered and directed by different interests to different ends. ${ }^{84}$

But the physical distance of Westminster did not erode the legal or political power of the state to develop a hierarchical and shared legal forum for the whole of the British Isles. As Colin Kidd has demonstrated, Scottish legal communities certainly drew inspiration from English common law to support the enlightenment drive for economic and commercial improvement. ${ }^{85}$ The nature of their interaction with the Lords underlines the extent that Scottish interests had a partial degree of autonomy: it was they who brought in the state here, co-opting it for their own ends and often for localised disputes; this would have not been the case with raising money to fund poor relief in Wales, imposing taxation, or building barracks in the Highlands. These appeals created thousands of links between Scottish communities and Westminster, and echoed the similar practice of 'propertied Englishmen' to avoid national interventions in their local communities. Legal cases, to the most part, did not seek the fundamental reform of institutions explicitly protected in the Union treaties during the first century of Union. Those few that did produced considerable opposition from the convention of royal burghs and led to a schism in Presbyterianism. The result was a piecemeal reform of Scottish institutions during the eighteenth century that only rarely altered the distinctive place of Scottish institutions, but did amend their exercise of power and that of landowners and magistrates through older Scots law.

Scottish autonomy during the eighteenth century was only a partial one. Local rivals and clashing interests did appeal to Westminster to umpire their conflicts, and in doing so remade and redefined long-standing privileges and powers of Scottish institutions. The expansion of the British state is often portrayed as the result of party-conflict, parliamentary 
LITIGATION AND THE UNION OF 1707

legislation and the extension of executive power through the growth of the fiscal-military state. But together with the importance of thousands of local acts of parliament, the continuing relevance of lawsuits makes it clear that English and aristocratic power was far from the sole source of initiative or change. The political cultures and political economies of both Scottish and British society were thus far more multi-centred and locally-conditioned than has so far been established. 
Graph 1: Number of appeals, 1660-1875 per session and sitting day (seven session moving average)

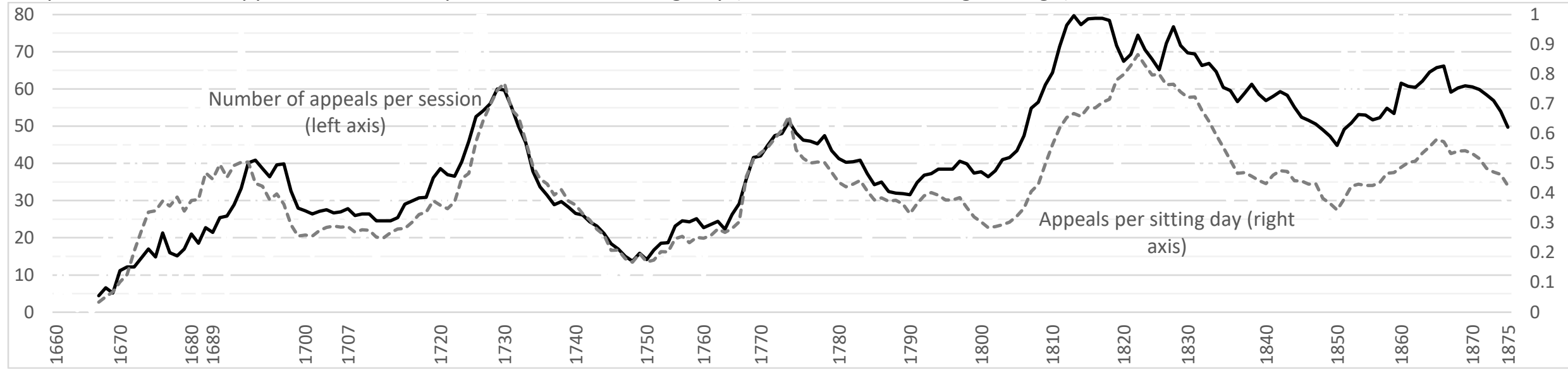

Graph 2: Number of appeals from each nation, 1660-1875 (seven session moving average)

60

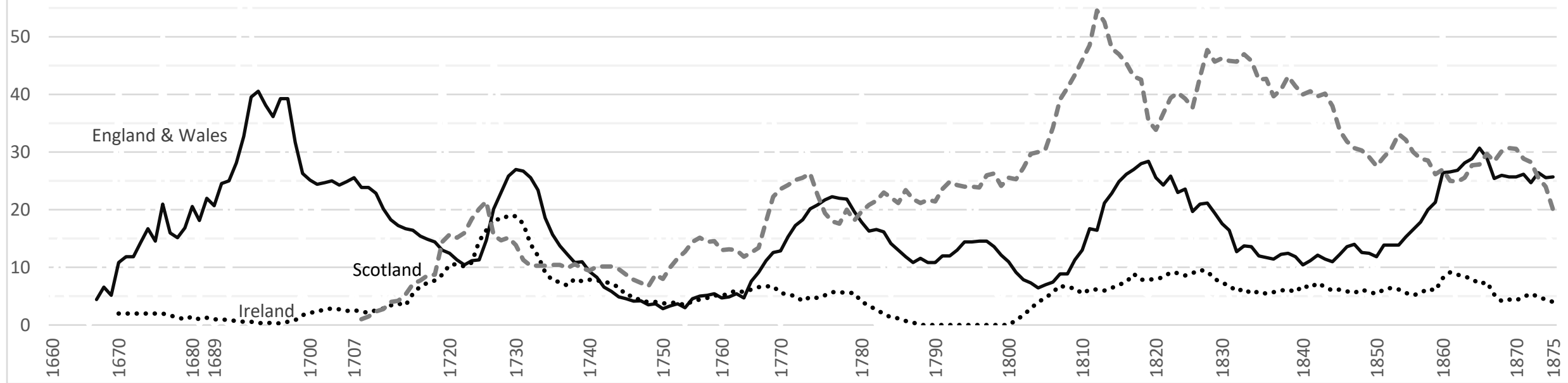

Sources: L.J, xi-cvii; Report...[on] the judicature of the Court of Session (London, 1808), pp. 16-19; Accounts relating to appeals, and writs of error (London, 1823), pp. 17-21; Report...on...the courts of law in Scotland (London, 1824), pp. 290-365; Report...on the supreme court of judicature in Scotland (London, 1840), pp. 246, 255; A return of the number of causes appealed...from the Court of Session (London, 1840), p. 280; Return of the number of causes presented to the House of Lords from the year 1835 to the year 1855 (London, 1856), p. 298; Judicial statistics (London, 1859-1875); Sittings of the house 1831-2 to 1881 (London, 1881). 
Graph 3: Cases presented to British law courts, 1745-1875.

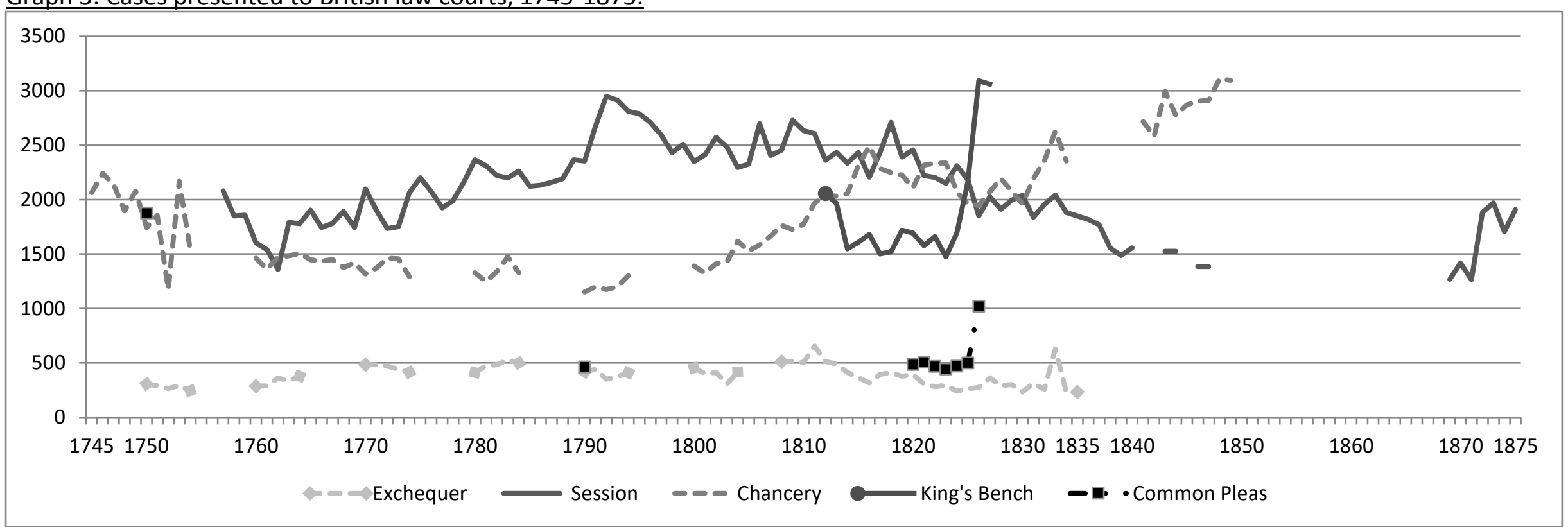

Sources: Exchequer: First report...to inquire into...the superior courts of common law (London, 1829), p. 11; Return of all appeals presented, and writs of error...from 1790 to 1835 (London, 1836), pp. 21-2. Session: C.F. Shand, The practice of the Court of Session (2 vols., Edinburgh, 1848), II, pp. 4-5; Report...inquiring into...the courts of law in Scotland (London, 1824), pp. 231-2, 235-6; An abstract...of business...in the Court of Session since the year 1780 (London, 1843), pp. 3-4; Report...on the supreme court of judicature in Scotland (London, 1850), p. 61; First to sixth reports on the judicial statistics of Scotland (London, 1871-6). Chancery: Report...into the causes...in...Chancery (London, 1811), p. 32; Chancery and Exchequer. Return of all appeals...from 1790 to 1835 (London, 1836), pp. 21-2; Appeal causes, heard...in...Chancery...from 1841 to 1850 (London, 1850). King's Bench: Number of causes...in...the King's Bench (London, 1820), pp. 1-4; Court of King's Bench. Return of the number of causes (London, 1829), p. 1; First report...into the...courts of common law (London, 1829), p. 11; C. Brooks, Lawyers, litigation, and English society since 1450 (London, 1998), pp. 31, 68. Common Pleas: Causes entered for trial in...Common Pleas [1820-26] (London, 1826), pp. 1-3; First report...to inquire into...the superior courts of common law, p. 11; Brooks, Lawyers, pp. 31, 68. 
Table 1: Subjects of appeals by nation in sample sessions, 1660-1875 (as percentage and number of prosecuted appeals)

\begin{tabular}{|c|c|c|c|c|c|c|c|c|c|c|}
\hline & $\begin{array}{c}\text { Estates \& } \\
\text { inheritance }\end{array}$ & $\begin{array}{l}\text { Land } \\
\text { titles }\end{array}$ & $\begin{array}{c}\text { Debts \& } \\
\text { bonds }\end{array}$ & $\begin{array}{l}\text { Business } \\
\text { disputes }\end{array}$ & Transport & $\begin{array}{l}\text { Markets } \\
\text { and tax }\end{array}$ & $\begin{array}{c}\text { Church \& } \\
\text { tithes }\end{array}$ & Elections & Misc. & $\begin{array}{c}\text { Unproc } \\
\text { cases }\end{array}$ \\
\hline \multicolumn{11}{|c|}{ ENGLAND AND WALES } \\
\hline $1660-1707$ & $30.2(46)$ & $23.7(36)$ & $27.6(42)$ & $3.9(6)$ & $3.3(5)$ & $3.3(5)$ & $1.3(2)$ & $0.0(0)$ & $6.5(10)$ & n/a (15) \\
\hline $1708-1750$ & $40.9(29)$ & $15.5(11)$ & $22.5(16)$ & $5.6(4)$ & $0.0(0)$ & $4.2(3)$ & $5.6(4)$ & $0.0(0)$ & $5.6(4)$ & $\mathrm{n} / \mathrm{a}(17)$ \\
\hline $1751-1800$ & $36.7(11)$ & $26.7(8)$ & $23.3(7)$ & $3.3(1)$ & $6.7(2)$ & $0.0(0)$ & $0.0(0)$ & $0.0(0)$ & $3.3(1)$ & $\mathrm{n} / \mathrm{a}(13)$ \\
\hline $1801-1875$ & $48.0(48)$ & $11.0(11)$ & $21.0(21)$ & $3.0(3)$ & $5.0(5)$ & $0.0(5)$ & $6.0(6)$ & $0.0(0)$ & $6.0(6)$ & $\mathrm{n} / \mathrm{a}(18)$ \\
\hline \multicolumn{11}{|c|}{ IRELAND } \\
\hline $1660-1707$ & $80.0(4)$ & $20.0(1)$ & $0.0(0)$ & $0.0(0)$ & $0.0(0)$ & $0.0(0)$ & $0.0(0)$ & $0.0(0)$ & $0.0(0)$ & $\mathrm{n} / \mathrm{a}(0)$ \\
\hline $1708-1750$ & $33.3(18)$ & 35.2 (19) & $18.5(10)$ & $3.7(2)$ & $0.0(0)$ & $1.9(1)$ & $7.4(4)$ & $0.0(0)$ & $0.0(0)$ & $\mathrm{n} / \mathrm{a}(8)$ \\
\hline $1751-1801$ & $38.9(7)$ & $33.3(6)$ & $22.2(4)$ & $0.0(0)$ & $0.0(0)$ & $0.0(0)$ & $0.0(0)$ & $0.0(0)$ & $5.6(1)$ & $\mathrm{n} / \mathrm{a}(5)$ \\
\hline $1800-1875$ & $58.5(24)$ & 31.7 (13) & $7.3(3)$ & $0.0(0)$ & $0.0(0)$ & $2.4(1)$ & $0.0(0)$ & $0.0(0)$ & $0.0(0)$ & $\mathrm{n} / \mathrm{a}(1)$ \\
\hline \multicolumn{11}{|c|}{ SCOTLAND } \\
\hline $1708-1750$ & $23.4(15)$ & $31.2(20)$ & $23.4(15)$ & $3.1(2)$ & $0.0(0)$ & $1.6(1)$ & $9.4(6)$ & $3.1(2)$ & 4. 7 (3) & $\mathrm{n} / \mathrm{a}(5)$ \\
\hline $1751-1800$ & $15.1(16)$ & $23.6(25)$ & $25.5(27)$ & $9.4(10)$ & $0.0(0)$ & $8.5(9)$ & $2.8(3)$ & $12.3(13)$ & $2.8(3)$ & $\mathrm{n} / \mathrm{a}(10)$ \\
\hline $1801-1875$ & $34.8(101)$ & $18.3(53)$ & $14.8(43)$ & $9.0(26)$ & $5.5(16)$ & $5.5(16)$ & $5.2(15)$ & $1.0(3)$ & $4.5(13)$ & $\mathrm{n} / \mathrm{a}(18)$ \\
\hline
\end{tabular}

Raw numbers in brackets. Sources: see footnote twelve. 
Graph 4: Decisions on Scottish appeals, 1707-1840

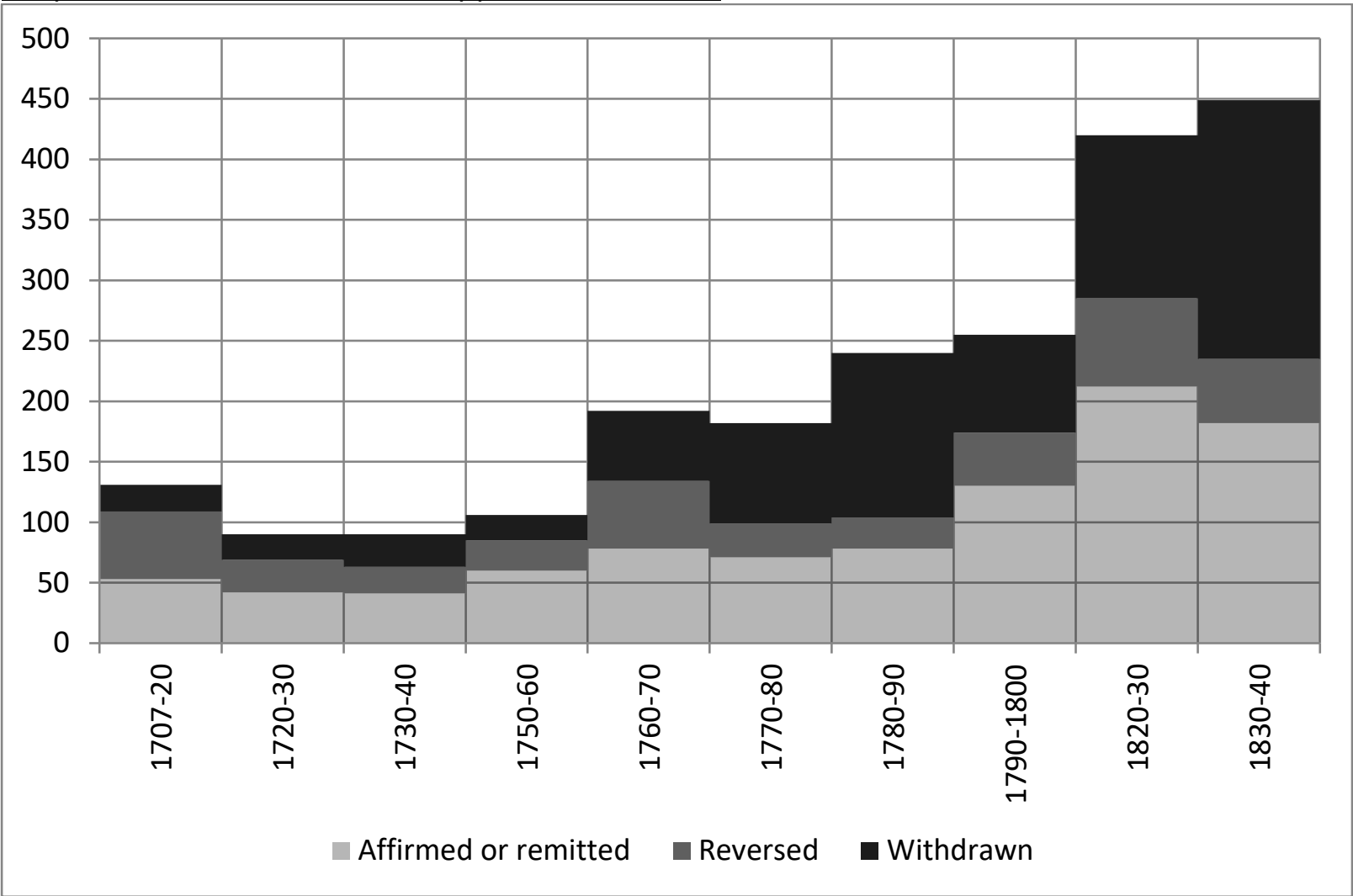

Sources: L.J, xviii-xxix; xxxviii-xlii [1707-1760, 1790-1800]; Report...on forms of process in the courts of law in Scotland (London, 1824), p. 344 [1760-1790]; Return of the number of causes appealed to the House of Lords from the...Session (London, 1840), p. 280 [1820-40].

Graph 5: Relationship between the number of appeals and days spent hearing, 1756-1792 (seven session moving average)

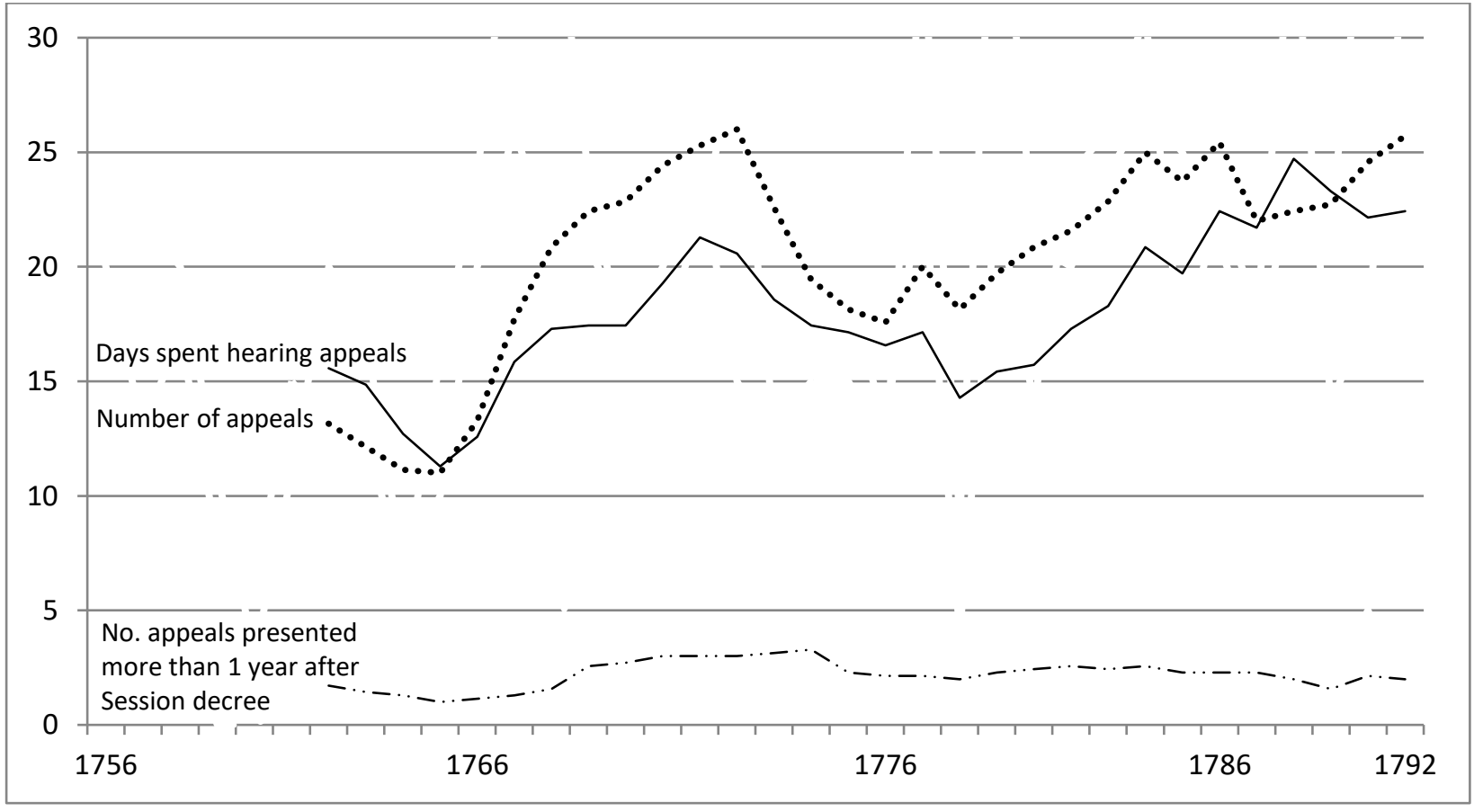

Source: Report...on forms of process in the courts of law in Scotland (London, 1824), p. 345. 
Graph 6: Decisions on Scottish appeals that went to judgement, 1707-1875

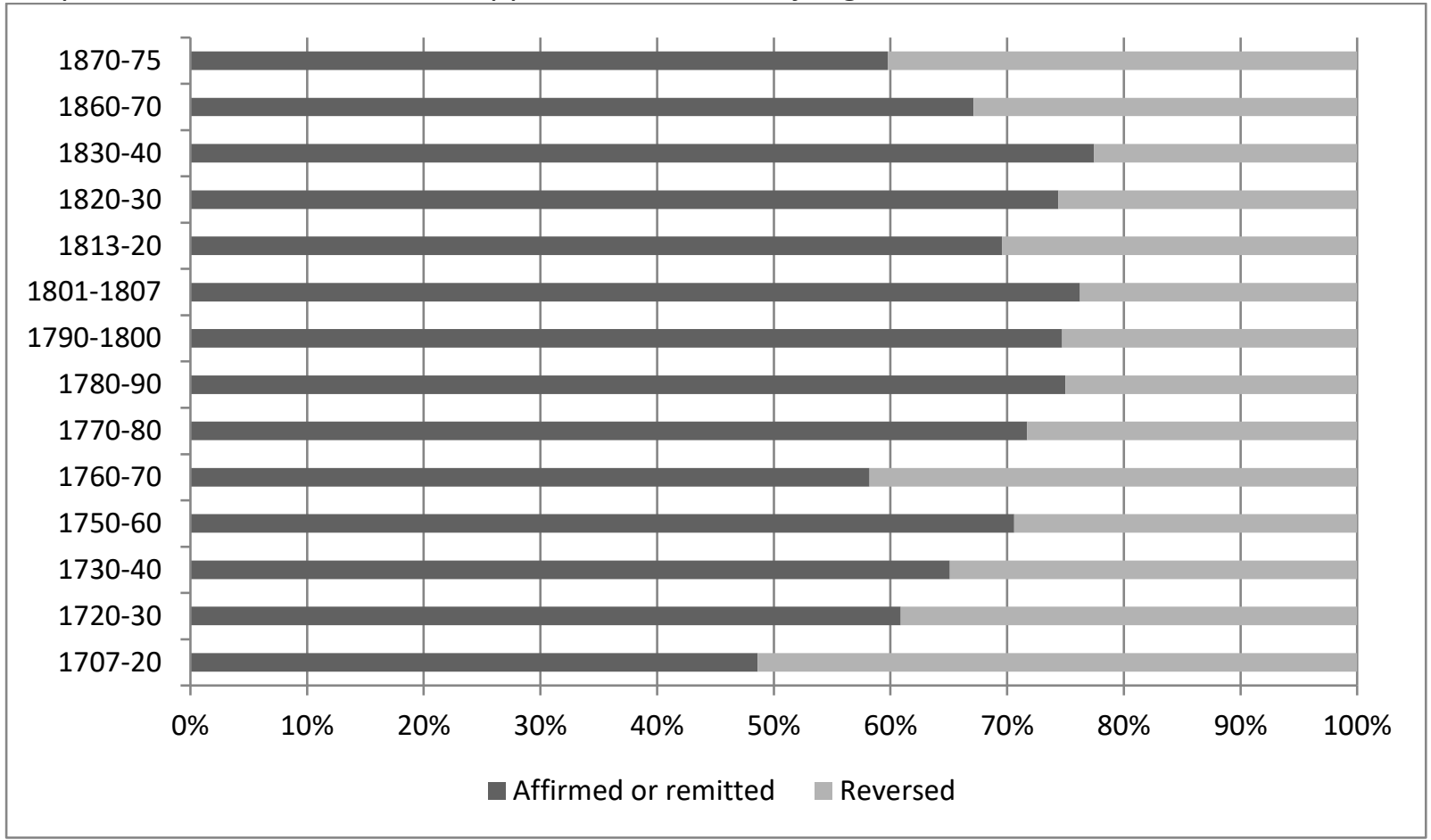

Sources: see graph four and Report...respecting...the Court of Session (London, 1808), pp. 1617 [1801-7]; Accounts relating to appeals and writs (London, 1823), pp. 2-3 [1813-20]; Judicial statistics (London, 1860-1875) [1860-75]. Figures after 1860 are based solely on those that went to trial, so underestimate those that were dismissed for want of prosecution. 
Map 1. Distribution of Scottish appeals, per thousand inhabitants, 1707-1800

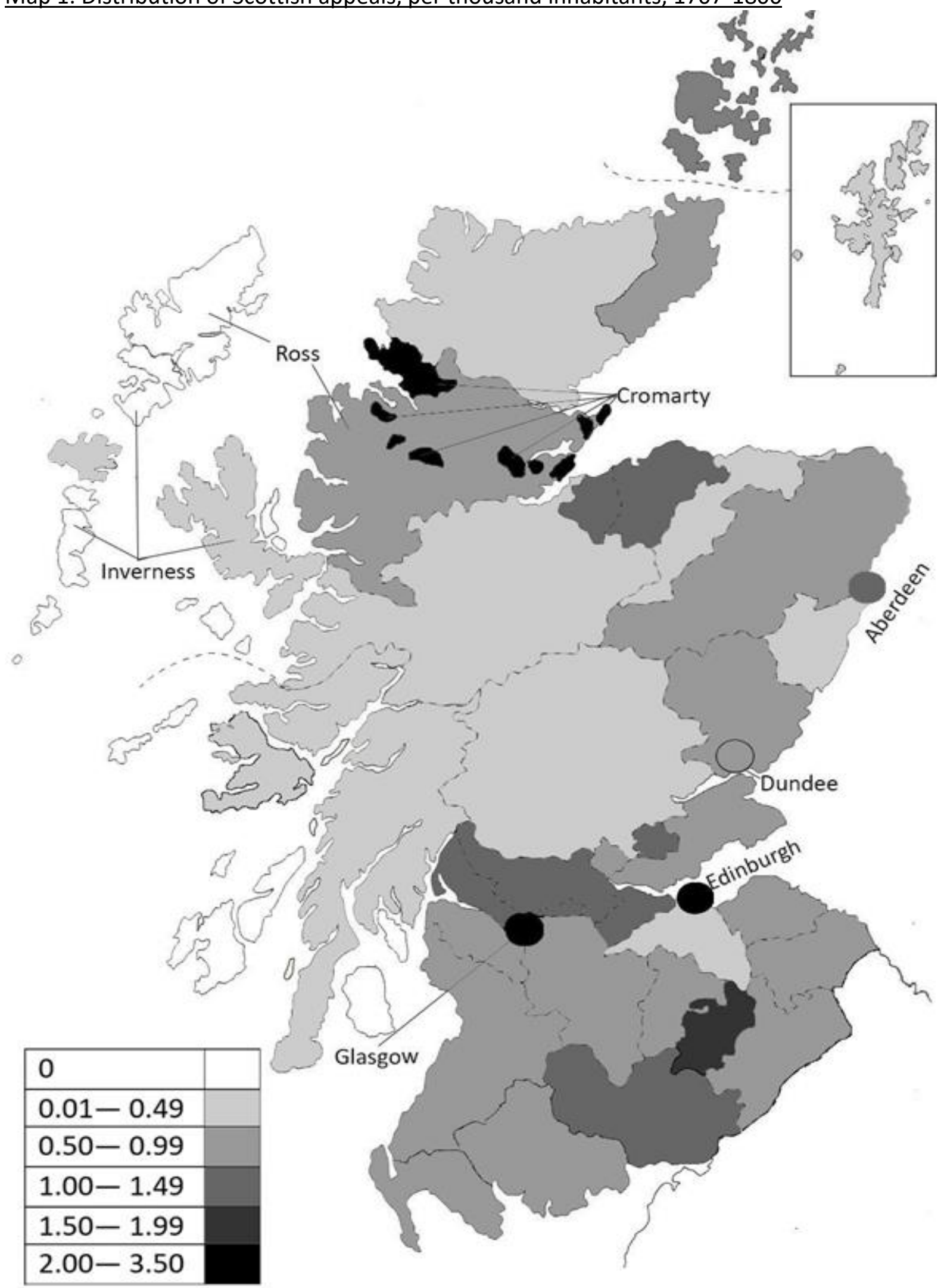

Sources: See footnote twelve and Hamilton, Economic history, appendix 1. 
Faculty of History, West Road, Cambridge, CB3 9EF.

* Many thanks are due to Phil Withington and the anonymous readers for their comments. This article has also benefited from the feedback of seminar participants in Liverpool, Oxford, Edinburgh, the Institute of Historical Research, and the British Legal History Conference. I gratefully acknowledge the financial support of the Arts and Humanities Research Council and the British Academy (grant pf160004).

${ }^{1}$ J. Hoppit, 'Patterns of parliamentary legislation, 1660-1800', Historical Journal, 39 (1996), pp. 109-31; J. Innes, 'Legislating for three kingdoms: how the Westminster parliament legislated for England, Scotland and Ireland, 1707-1830', in J. Hoppit, ed., Parliaments, nations and identities in Britain and Ireland, 1660-1850 (Manchester, 2003), pp. 15-47.

${ }^{2}$ N. Phillipson, The Scottish whigs and the reform of the Court of Session, 1785-1830 (Edinburgh, 1990), p. 85; J. Finlay, 'Scots lawyers and House of Lords appeals in eighteenth-century Britain', Legal History, 32 (2011), pp. 249-77, at p. 275.

${ }^{3}$ S. Connolly, R. Houston, and R. Morris, 'Identity, conflict and economic change: themes and issues', in S. Connolly, R. Houston and R. Morris, eds., Conflict, identity and economic development: Ireland and Scotland, 1600-1939 (Preston, 1995), p. 2.

${ }^{4}$ P.H. Scott, Still in bed with an elephant (Edinburgh, 1985); L. Kennedy, In bed with an elephant: a journey through Scotland's past and present (London, 1995).

5 J. Hoppit, Parliament and Britain's political economies, 1660-1800 (Cambridge, 2017), ch. 4; B. Harris, 'Scotland's herring fisheries and the prosperity of the nation, c. 16601760', Scottish Historical Review, 79 (2000), pp. 39-60. 
${ }^{6}$ Phillipson, The Scottish whigs; G. Pentland, Radicalism, reform and national identity in Scotland, 1820-1833 (Woodbridge, 2008).

${ }^{7}$ Innes, 'Legislating for three kingdoms', pp. 21, fig. 2.4, 22.

${ }^{8}$ L.J, xviii-xxvii; C.J, xvi-xxvi.

${ }^{9}$ B. Jewell, 'The legislation relating to Scotland after the forty-five' (PhD, North Carolina, 1975); A. MacKillop, 'The political culture of the Scottish Highlands from Culloden to Waterloo', Historical Journal, 46 (2003), pp. 511-32, at pp. 521-4.

${ }^{10} \mathrm{~B}$. Harris, 'The Scots, the Westminster parliament, and the British state in the eighteenth century', in Hoppit, ed., Parliaments, nations and identities, pp. 124-45, at pp. 133, 136-8; Hoppit, Britain's political economies, pp. 112-22.

${ }^{11}$ Scots law did not maintain a distinctive Scottish identity, see C. Kidd, Union and unionisms, political thought in Scotland, 1500-2000 (Cambridge, 2008), ch. 5; H. MacQueen, "Regiam majestatem", Scots law, and national identity', Scottish Historical Review, 74 (1995), pp. 1-25.

12 L.J, xi-cvii; Parliamentary archives, HL/PO/JU/4/3/1-298; HL/PO/JO/10/1/283-525; $\mathrm{HL} / \mathrm{PO} / \mathrm{JO} / 10 / 6-9$. The exception are cases that went unprosecuted, for which only a record in the L.J of their presentation exists.

${ }^{13}$ Criminal appeals from the Justiciary were outlawed in the 1770 s, see N. Williams, Final appellate jurisdiction in the Scottish legal system (Edinburgh, 2010), p. 22.

${ }^{14}$ Its post-1876 role is examined in L. Blom-Cooper, B. Dickson and G. Drewry, eds., The judicial House of Lords, 1876-2009 (Oxford, 2009). J. Hart, Justice upon petition: The House of Lords and the reformation of justice, 1621-1675 (London, 1991), surveys its seventeenth-century history. 
${ }^{15}$ R. Atkins, An enquiry into the jurisdiction of the Chancery in causes of equity (London, 1695), p. 27; J. Swift, Gulliver's travels (Oxford, 1986), p. 116.

${ }^{16}$ Hoppit, 'Patterns of parliamentary legislation', pp. 110, 112.

${ }^{17}$ D. Lemmings, Professors of the law: barristers and English legal culture in the eighteenth century (Oxford, 2000), pp. 11, 91, 95-7, 190; H. Horwitz, 'Chancery's “younger sister": the court of Exchequer and its equity jurisdiction, 1649-1841', Historical Research, 72 (1999), pp. 160-82, at pp. 168-9, 172.

${ }^{18}$ D. Hayton, The Stanhope/Sunderland ministry and the repudiation of Irish parliamentary independence', English Historical Review, 113 (1998), pp. 610-36.

${ }^{19}$ A. Rees, 'The practice and procedure of the House of Lords, 1714-1784' (PhD, University of Wales, 1987), p. 138.

${ }^{20}$ Standing orders of the House of Lords (London, 1844), pp. 24-7, 56, 63-4.

${ }^{21}$ J. D. Ford, 'Protestations to parliament for remeid of law', Scottish Historical Review, 88 (2009), pp. 57-107, at p. 95.

22 Phillipson, The Scottish whigs, p. 53.

${ }^{23} \mathrm{H}$. Hamilton, An economic history of Scotland in the eighteenth century (Oxford, 1963), appendix I; E. A. Wrigley, 'British population during the "long" eighteenth century, 1680-1840', in R. Floud and P. Johnson, eds., The Cambridge economic history of modern Britain (3 vols., Cambridge, 2004), I, pp. 57-95, at p. 64, table 3.1.

${ }^{24}$ J. Cairns, 'Historical introduction', in K. Reid and R. Zimmermann, eds., A history of private law in Scotland: 1. Introduction and property (Oxford, 2000), pp. 142-55; Report on the supreme court of judicature in Scotland (London, 1840), pp. 18, 131, 156.

25 Standing orders, pp. 118-19.

${ }^{26}$ Report...on the supreme court of judicature, p. 79; Phillipson, The Scottish whigs, p. 47. 
${ }^{27}$ Report...on the supreme court of judicature, pp. 9, 61, 74-5, 79, 144, 233, 241-2.

${ }^{28}$ Finlay, 'Scots lawyers', p. 258.

${ }^{29}$ The Scots statutes revised: the acts of the parliaments of Scotland, 1424-1707 (Edinburgh, 1908), pp. 200-8.

${ }^{30}$ Due to their small number, Welsh appeals have been included with England. There were only forty between 1689 and 1720, and four between 1813 and 1823 .

${ }^{31}$ Because of the greater variation in the number of appeals each session during the Restoration, a single average of twenty-one was used to select sample sessions.

${ }^{32}$ D. Robertson, Reports of cases on appeal from Scotland, decided in the House of Peers (London, 1807), I, pp. 1-3.

${ }^{33}$ E. J. Dawson, 'Finance and the unreformed borough: a critical appraisal of corporate finance 1660 to 1835 , with special reference to the boroughs of Nottingham, York and Boston' (PhD, Hull, 1978), pp. 380-403.

34 J. Philip, 'Some reflections on desuetude', Juridical Review, 43 (1931), pp. 260-7.

${ }^{35}$ B. Harris, 'Scots burghs, "privilege" and the Court of Session in the eighteenth century', Urban History, 44 (2017), pp. 1-21.

${ }^{36}$ Robertson, Reports of cases, I, pp. 124-9; H. Armet, ed., Extracts from the records of the burgh of Edinburgh, 1689-1701 (Edinburgh, 1962), pp. 134-5.

${ }^{37}$ R. Renwick, ed., Extracts from the records of the burgh of Glasgow, A.D. 1718-38 (Glasgow, 1909), pp. 40-1, 471, 487.

${ }^{38} \mathrm{~T}$. Paton, Reports of cases decided in the House of Lords upon appeal from Scotland from 1726 to 1821 (6 vols., Edinburgh, 1849-1856), VI, pp. 1-5.

${ }^{39}$ P. Dow, Reports of cases upon appeals and writs of error in the House of Lords (6 vols., London, 1814-19), V, pp. 282-92. 
${ }^{40}$ Aberdeen Journal, 17 March 1825, Issue 3975; Caledonian Mercury, 20 March 1824, Issue 16006; 27 March 1824, Issue 16009; 11 March 1826, Issue 16311; The Morning Post, 10 March 1824, Issue 16505; 19 April 1827, Issue 17580.

${ }^{41}$ Dow, Report of cases, II, pp. 40-66.

42 P. Langford, Public life and the propertied Englishman, 1689-1798 (Oxford, 1991), pp. 15666.

43 Paton, Reports, I, pp. 645-9.

${ }^{44}$ I. A. Robertson, 'The Tay salmon fisheries in the nineteenth century' (PhD, Stirling, 1989), pp. 222-6; J. F. Macqueen, Reports of Scotch appeals and writs of error, together with peerage, divorce and practice cases in the House of Lords (4 vols., Edinburgh, 185566), IV, pp. 535-59.

45 Macqueen, Reports of Scotch appeals, I, pp. 2-35.

${ }^{46}$ The best account of the Scottish electorate remains W. Ferguson, 'Electoral law and procedure in eighteenth and early nineteenth-century Scotland' (2 vols., PhD, Glasgow, 1957).

${ }^{47}$ Information for Alexander Penrose Cumming...against John Lawson [in the high court of the justiciary] (n.p, 1785), pp. 12, 14; The Edinburgh Review for October, 1830...January 1831 (250 vols., Edinburgh, 1802-1929), LII, p. 223.

${ }^{48}$ Ferguson, 'Electoral law', I, pp. 15-23, 45, 49-51.

${ }^{49}$ The Scots Magazine (Edinburgh, 1768), xxx, pp. 163-4; L. Namier and J. Brooke, eds., The House of Commons, 1754-1790 (3 vols., London, 1964), I, p. 482; Report of the commissioners...into... appeals from the Court of Session to the House of Lords (London, 1824), pp. 297-8. 
${ }^{50}$ R. Thorne, ed., The House of Commons, 1790-1820 (5 vols., London, 1986), II, pp. 571-2; R. Bligh, Reports of cases heard in the House of Lords on appeals and writs of error, and decided during the session 1819 (4 vols., London, 1823-7), I, pp. 163, 209.

${ }^{51}$ Thorne, ed., The House of Commons, II, pp. 72, 512; Paton, Reports, III, pp. 169-88.

${ }^{52} \mathrm{~T}$. Keith, 'The trading privileges of the royal burghs of Scotland (continued)', English Historical Review, 28 (1913), pp. 678-90, at p. 687.

${ }^{53}$ W. M. Morison, The decisions of the Court of Session: from its first institution to the present time (38 vols., Edinburgh, 1801-08), III, p. 1908; T. Pagan, The convention of royal burghs of Scotland (Glasgow, 1926), p. 136.

${ }^{54}$ Extracts from the records of the convention of the royal burghs of Scotland, 1759-79 (Edinburgh, 1918), p. 351.

${ }^{55}$ Extracts from the records of the convention of royal burghs of Scotland, 1738-59 (Edinburgh, 1915), pp. 18, 257-8, 270, 307-8, 399, 516, 533; Abstract of facts, respecting the revenues of the royal boroughs of Scotland (London, 1788), pp. 58, 60 .

56 Pagan, Convention of royal burghs, pp. 62-63, 146.

${ }^{57}$ W. Ward, 'The land tax in Scotland, 1707-98', Bulletin of the John Rylands Library, 37 (1954), pp. 288-308, at pp. 292-3, 296.

${ }^{58} \mathrm{~A}$. Porteous, The town council seals of Scotland, historical legendary and heraldic (Edinburgh, 1906), p. 179.

59 J. Stephen, Defending the revolution: the church of Scotland, 1689-1716 (London, 2013), pp. $165-80$.

${ }^{60}$ Robertson, Reports of cases, I, pp. 12-16.

61 Kidd, Union and unionisms, pp. 221, 223.

${ }^{62}$ F. Lyall, Church and state in Scotland: developing law (Oxford, 2016), pp. 32-8. 
${ }^{63}$ Lord Roger of Earlsferry, The courts, the church and the constitution: aspects of the disruption of 1843 (Edinburgh, 2008), pp. 3-30.

${ }^{64}$ Report...on forms of process in the courts of law in Scotland (London, 1824), pp. 306-43.

${ }^{65}$ T. C. Hansard, The parliamentary debates, second series (25 vols., London, 1824), X, p. 386.

${ }^{66}$ L.J, Ixxxiv, p. 49.

${ }^{67}$ Minutes of proceedings of the select committee on the royal burghs of Scotland (London, 1821), p. 25; Magistrates and town council of the town of Montrose (n.p., 1714), pp. $1-5$.

${ }^{68}$ Finlay, 'Scots lawyers', pp. 257-8. There were only two cases represented by two Scottishbased counsel before the late 1740s.

${ }^{69}$ Robertson, Reports of cases, I, pp. 617-19.

70 D. Feutry, 'The historian's mountain of paper: the parlement of Paris and the analysis of civil suits in the eighteenth century', French History, 26 (2012), pp. 277-96, at pp. 287-8; R. Kagan, Lawsuits and litigants in Castile 1500-1700 (Chapel Hill, 1981), p. 100.

${ }^{71}$ Rees, 'Practice and procedure', p. 161.

72 Letters of Lord Balmerino to Harry Maule, 1710-1713, 1721-1722, ed. C. Jones (Miscellany of the Scottish history society, fifth series, vol. 12, Edinburgh, 1994), pp. 99-168, at pp. 109, 127; D. Szechi, 'The politics of "persecution": Scots Episcopalian toleration and the Harley ministry, 1710-12', in W. Sheils, ed., Studies in church history: toleration and persecution, 21 (1984), pp. 275-87, at p. 281.

${ }^{73}$ Hoppit, Britain's political economies, pp. 102-7, summaries this approach. 
${ }^{74}$ Horwitz, 'Exchequer', p. 171, table 3; Idem and Polden, 'Continuity or change in the Court of Chancery in the seventeenth and eighteenth centuries?', Journal of British Studies, 35 (1996), pp. 24-57, at p. 50, table 17; C. Brooks, Pettyfoggers and vipers of the commonwealth: The 'lower branch' of the legal profession in early modern England (Cambridge, 1986), p. 64, table 4.4.

75 The University of Virginia has mapped cases from 1750 to 1800, <http://archives.law.virginia.edu/scos/casemap>, January 2015.

${ }^{76}$ Hoppit, Britain's political economies, p. 114, table 4.3.

77 Hoppit, Britain's political economies, pp. 335-6.

${ }^{78}$ Namier and Brooke, eds., The House of Commons 1754-1790, I, p. 476.

${ }^{79}$ Ferguson, Electoral law, II, pp. 217-18, 251, 256.

${ }^{80}$ Ferguson, Electoral law, I, p. 200; L.J, xxxii, pp. 464-5.

81 L.J, xxxii, pp. 118, 444, 664; xxxviii, p. 607; Thorne, ed., The House of Commons, I, p. 529.

82 Paton, Reports, I, pp. 302, 586; VI, p. 709; L.J, xxiv, pp. 231, 239; xxv, pp. 540, 576; xxxvii, p. 402 ; xxviii, pp. 326,607 .

${ }^{83}$ P. King and R. Ward, 'Rethinking the bloody code in eighteenth-century Britain: capital punishment at the centre and on the periphery', Past and Present, 228 (2015), pp. 159-205; J. Innes, 'What would a 'four nations' approach to the study of eighteenthcentury British social policy entail?', in S. J. Connolly, ed., Kingdoms united? Great Britain and Ireland since 1500 (Dublin, 1999), pp. 181-99.

${ }^{84} \mathrm{C}$. Storrs, ed., The fiscal-military state in eighteenth-century Europe: essays in honour of P.G.M. Dickinson (Farnham, 2009), chs. 3 and 5.

${ }^{85}$ Kidd, Union and unionisms, ch. 5. 